\title{
Somatic characteristics in relation to meeting recommended physical activity in overweight and obese women aged 30-60 years
}

\author{
Tereza Sofkováa ${ }^{1, *}$ and Miroslava Přridalová ${ }^{2}$ \\ ${ }^{1}$ Faculty of Education, Palacký University Olomouc, Olomouc, Czech Republic; ${ }^{2}$ Faculty of Physical Culture, Palacký Uni- \\ versity Olomouc, Olomouc, Czech Republic
}

Copyright: (c) 2015 T. Sofková and M. Přidalová. This is an open access article licensed under the Creative Commons Attribution License (http://creativecommons.org/licenses/by/4.0/).

\begin{abstract}
Background: Physical activity (PA) can provide health benefits and thus reduce the risk of complications from obesity and improve mental well-being. We consider body composition as an acceptable indicator of the functional condition of the body. Aims: Our research objective was to analyse selected body composition fractions in relation to meeting recommended PA in overweight and obese women. Methods: 221 women participated in our study, divided in two age groups: 30 to 44.9 years (Maturus I, $n=118$ ) and 45 to 60 years (Maturus II, $n=103$ ). Each age group was further differentiated by sub-groups (adequate and inadequate PA) according to the achieved PA level (medium PA: 3 to 6 MET; $\geq 150 \mathrm{~min} /$ week). To determine the PA parameters within one week the ActiGraph GT1M accelerometer was used. The InBody 720 body composition analyser was used to determine body composition parameters. Descriptive characteristics and data analysis were carried out using Statistica 10.0. Differences were compared by the Student's $t$-test. Statistical significance level was set at $\alpha<.05$. Results: Younger women who achieved adequate PA reached lower average values of body fat mass and visceral fat area than women with inadequate PA. Higher average values of the fat-free mass, body cell mass and skeletal muscle mass were found in older women with adequate PA in comparison with women with inadequate PA. Conclusions: The research study verified a positive relationship between meeting the recommended PA level and its impact on body composition health risk indicators. A positive approach to the PA may lead to a decrease in health problems associated with excess weight and obesity.
\end{abstract}

Keywords: obesity, healthy lifestyle, body composition, accelerometer

\section{Introduction}

The accelerated pace of natural life and consumerism result in an increase in obesity. Sedentary lifestyle and obesity are among the most discussed health topics across all society; they are usually associated with health problems. The WHO (2004) names the indirect fundamental causes of obesity as increasing urbanisation, industrialisation and disappearance of traditional lifestyles with direct factors of sedentary lifestyle and high-energy diets. Lack of regular physical activity (PA) is also associated with increased obesity which has major impact on human health. Our health is also negatively influenced by deterioration of environmental conditions and higher psychological stress, both

\footnotetext{
* Address for correspondence: Tereza Sofková, Department of Anthropology and Health Education, Faculty of Education, Palacký University Olomouc, Žižkovo nám. 5, 77140 Olomouc, Czech Republic. E-mail: tereza.sofkova@upol.cz
}

typical in today's modern times (Doll, Petersen, \& Stewart-Brown, 2000; Hoeger \& Hoeger, 2009).

Sedentary lifestyle is associated with health problems and also becomes a psychological and social risk (Kalvach, Zadák, Jirák, Zavázalová, \& Sucharda, 2004). PA is one way how to positively influence physical and mental health. Lack of PA and a preference to a sedentary lifestyle lead to fading physical condition which causes the elderly population premature loss of self-sufficiency and significantly impairs their quality of life. Varo et al. (2003) indicate that the prevalence of sedentary lifestyle in the EU is at a high level and with increasing age of the population the number of inactive people increases.

A decrease in the level of PA is significantly modified by exogenous factors which include obesity, smoking and the level of educational attainment. Obese individuals, smokers and people with secondary or university education have lower levels of PA (Norman, Bellocco, Vaida, \& Wolk, 2002). The study by 
Ball, Crawford, and Owen (2000) reported that excess weight in women is a barrier to PA in $6.2 \%$ and in obese women $22.6 \%$. Every year an increasing number of people are at risk of being overweight and obese and consequently there is a desire to find a natural way to encourage people to carry out key recommendations for implementing different types of PA. This should lead to improvement in the population's quality of life and result in significantly decreased health care costs related to the consequences of obesity.

Regular PA prevents obesity and it is a natural tool in reducing its prevalence as it relates to long-term maintenance of reduced body mass. It prevents the reduction of basal metabolic rate and restriction of fat-free mass. Regular PA promotes health and prevents the onset of a number of diseases, as well as improving social connectivity and quality of life (Andersen, 2003; Miles, 2007).

We consider the optimum body composition as an acceptable indicator of the functional condition of the body and its fitness. Good indicators of somatic condition are the body components, particularly fat and fat-free mass, and the body composition health indicators, such as the Body Fat Mass Index (BFMI), Fat-Free Mass Index (FFMI), Visceral Fat Area (VFA), Obesity Index (OI) and Body Cell Mass Index (BCMI). Long-term reduction in PA is reflected in inadequate representation of different body fractions and body composition health risk indicators (Heyward \& Wagner, 2004; Kyle, Morabia, Schutz, \& Pichard, 2004; Přidalová, Riegerová, Dostálová, \& Gába, 2008).

A key indicator which determines whether the effect of PA is maintaining the achieved weight loss is the level of PA. This is determined by the intensity and duration of the given PA and frequency of exercise units. PA should be carried out by rhythmic contractions of large muscle groups. Recommendations of the American Association of Sports Medicine states that the optimum aerobic exercise of medium intensity (such as brisk walking, 3 to $6 \mathrm{MET}$ ) at least 30 minutes for five days a week (150 min/week) should be undertaken by people who wish to maintain good health. Equally, combination of medium and high intensity exercise with duration of 30 respective 20 minutes is suggested. Exercise time may be divided into several shorter sections; each exercise must be at least 10 minutes long (Haskell et al., 2007). Saris et al. (2003) recommends walking, at least 10,000 steps/day, to maintain desired weight. For prevention of obesity 30 minutes of medium activity per day and for the prevention of recurrence of weight increase in previously obese people 60 to 90 minutes per day is recommended. Reduction of body mass and obesity in the population may be successfully carried out on the basis of professional recommendations regarding the prescription of the appropriate PA (Jeffery, Wing, Sherwood, \& Tate, 2003). Monitoring the PA to improve compliance with the recommended exercise regimen for overweight and obese women has been shown to have considerable influence and for the obese women is significantly motivating (Sofková, Přidalová, \& Pelclová, 2014).

An analysis of body composition can be used as a predictor for assessment of current somatic conditions. Searching for associations between body composition and PA especially in the group of overweight and obese females is needed. Consequently, there is a desire to find natural way to encourage people to carry out key recommendations for implementing different types of PA.

\begin{abstract}
Aim
Our research objective was to analyse selected body composition fractions in relation to meeting recommended seven day physical activity in overweight and obese women aged $30-60$ years.
\end{abstract}

\section{Methods}

Researched groups included 221 overweight and obese women from the Olomouc region within the age range of 30 to 60 years. Women were divided into two groups according to age: 30 to 44.9 years (Maturus I, $n=118$ ) and 45 to 60 years (Maturus II, $n=103$ ). In the first group (Maturus I) the average age was 38.4 years $(\mathrm{SD}=6.7)$ and in the second group (Maturus II) average age was 52.1 years $(S D=5.3)$. The age limit selection was based on literature review taking into account the onset of menopause (Cibula, Henzl, \& Živný, 2002; Fanta, 2007; Riegerová, Přidalová, \& Ulbrichová, 2006).

Seven day PA monitoring was carried out from 2011 to 2014, namely in January, April and September. Women were not briefed on the recommended level of PA in terms of the level and intensity within the weekly monitoring. For description in more detail, see below. Each age group was divided into two sub-groups (group with adequate PA and group with inadequate PA) according to the achieved PA level, either meeting or not meeting the recommended medium PA level in terms of intensity (PAme, 3 to 6 MET) and level $(\geq 150 \mathrm{~min} /$ week) (U.S. Department of Health and Human Services, 2008).

Each woman signed an agreement to carry out measurements and was introduced to the research particulars. Furthermore, the women were familiarised with 
the rules, as observance was essential to acquire valid data relating to body composition, instructed in accelerometer use and entry of data into the record sheet.

\section{Measurement methods}

Standardised anthropometric methods for the determination of key somatic parameters (body height, body weight) and somatic indices (Riegerová et al., 2006; WHO, 2004) were used in our investigation. For the assessment of excess weight and obesity the Body Mass Index (BMI) was used (normal mass: from 18.50 to $24.99 \mathrm{~kg} / \mathrm{m}^{2}$; overweight: 25.00 to $29.99 \mathrm{~kg} / \mathrm{m}^{2}$; obesity: 30.00 to $34.99 \mathrm{~kg} / \mathrm{m}^{2}$ ).

To diagnose body composition the InBody 720 body composition analyser (Biospace, Seoul, South Korea) using the direct multi-frequency bioelectrical impedance analysis method (DSM-BIA Method) was used. The principle of bioelectrical impedance method is based on differences in the propagation of high-frequency alternating electrical current of varying intensity in different biological structures. It is non-invasive and time saving method. The device differentiates body weight into three components - total body water (intracellular and extracellular fluid), dry matter (proteins and minerals) and body fat. The method is unified and measurement is carried out under standard conditions set by the device's instruction manual (Biospace, 2008). Prior to each measurement participants were familiarised with the rules, as observance was essential to acquire valid data relating to body composition.

One week monitoring of PA level and intensity and average daily number of steps was carried out using the ActiGraph GT1M (ActiGraph, Pensacola, FL, USA) accelerometer together with data entry into the record sheet. Women were instructed that the device must be worn at least 10 hours a day for seven days and only taken off for sleep or water related activities (swimming, hygiene). Seven day PA monitoring is considered sufficiently reliable in adults (Murphy, 2009; Trost, McIver, \& Pate, 2005).

\section{Data processing}

Data acquired by the InBody 720 Body Composition Analyser were processed using standard procedures using the LookinBody 3.0 software package (Biospace, Seoul, South Korea). Data measured by the ActiGraph GT1M were processed using software ActiPA 2006 (SoftWare Centrum, Olomouc, Czech Republic).

Descriptive characteristics and data analysis were carried out using the Statistica (Version 10; StatSoft, Tulsa, OK, USA). Differences in body composition between groups with various levels of PA were observed by Student's $t$-test. Statistical significance level was set at $p<.05$.

\section{Results}

In active women we recorded the average daily number of steps (HPA) to be as per recommended level (HPA, 10,000 steps/day) (Table 1). Average daily active energy expenditure (AEV, kcal) was greater in younger women, as well as the moderate PA (PAmo, 1 to 2.99 MET) and medium PA (PAme, 3 to 6 MET). Assessment of PA suggests that older women achieved general recommendation relating to medium PA (3 to 6 MET) better. Measurement results showed that the younger active women achieved average value of $289 \mathrm{~min} /$ week and older active women $299 \mathrm{~min} /$ week. Younger inactive women reached average of $97 \mathrm{~min} /$ week and older women $87 \mathrm{~min} /$ week (Figure 1).

Selected somatic characteristics differentiated by the group with adequate PA and group with inadequate PA are presented in Table 2. Total body water (TBW, 1) did not exceed the $50 \%$ threshold in any of the subgroups which corresponds to the assumption that the amount of TBW is in the reciprocal relationship to

Table 1

Differences analysis of selected physical activity indicators

\begin{tabular}{lccccc}
\hline & \multicolumn{2}{c}{ Maturus I $(n=118)$} & & \multicolumn{2}{c}{ Maturus II $(n=103)$} \\
\cline { 2 - 3 } \cline { 5 - 6 } & Adequate PA & Inadequate PA & & Adequate PA & Inadequate PA \\
\hline PAmo (min) & $73.3 \pm 29.6$ & $64.3 \pm 26.2$ & & $70.4 \pm 29.5$ & $60.3 \pm 24.7$ \\
PAme (min) & $41.3 \pm 16.7$ & $13.8 \pm 4.4^{*}$ & & $42.7 \pm 17.7$ & $12.4 \pm 5.9^{*}$ \\
AEV (kcal) & $691.2 \pm 253.5$ & $508.4 \pm 319.2^{*}$ & & $609.3 \pm 199.1$ & $406.3 \pm 160.8^{*}$ \\
HPA (step) & $10,586 \pm 2,809$ & $7,283 \pm 2,159^{*}$ & & $10,827 \pm 2,662$ & $6,964 \pm 1,508^{*}$ \\
\hline
\end{tabular}

Note. $\mathrm{PA}=$ physical activity, $\mathrm{PAmo}=$ moderate PA $(1$ to $2.99 \mathrm{MET}), \mathrm{PAme}=$ medium PA $(3$ to 6 MET), AEV = average daily active energy expenditure, HPA = average daily number of steps. Values are given as $M \pm S D$. *statistically significant difference between women with adequate and inadequate $\mathrm{PA}(p<.05)$. 


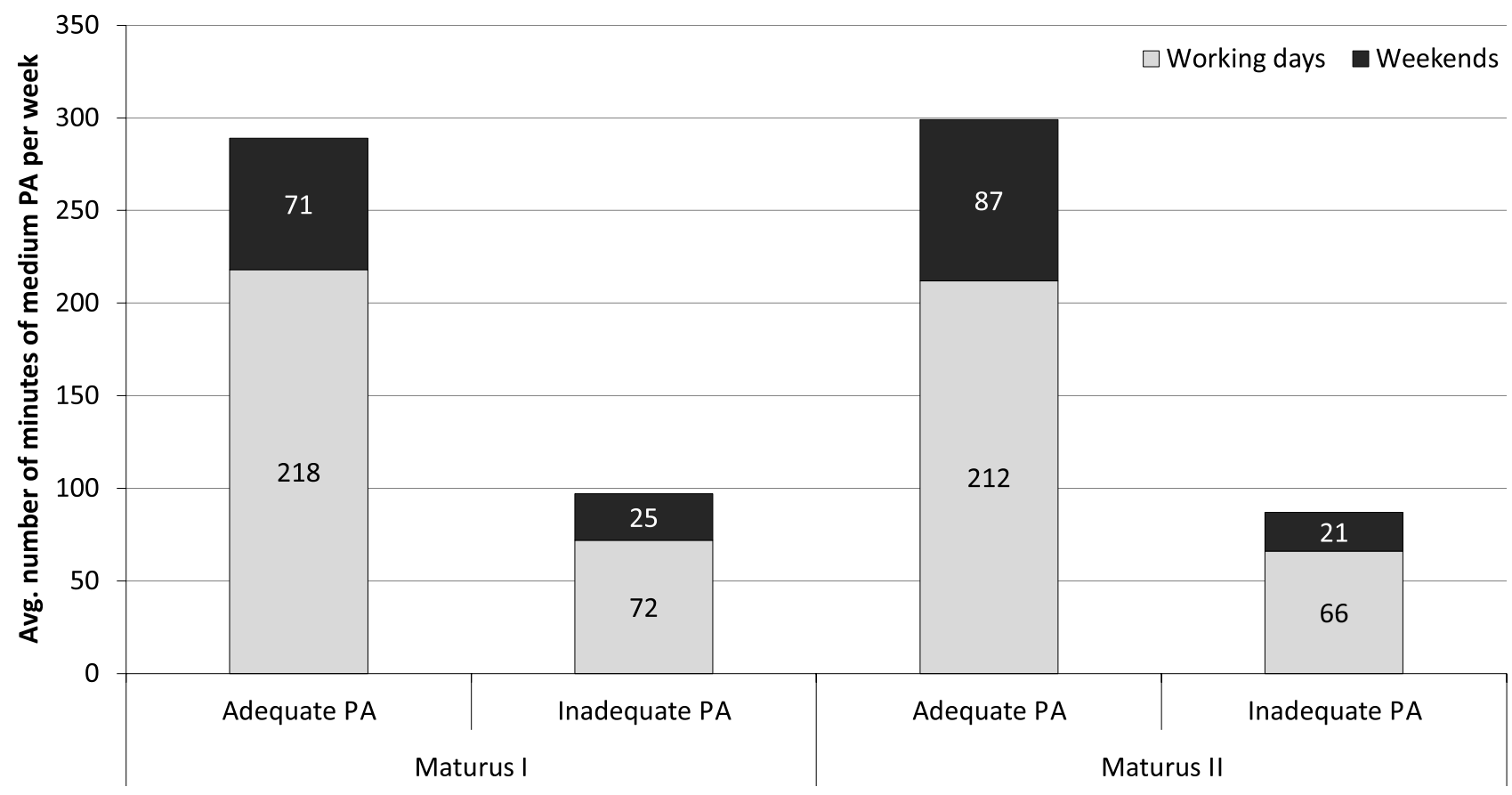

Figure 1. Comparison of weekly medium PA (3 to 6 MET) in women groups

Table 2

Selected somatic characteristics in relation to the age and physical activity

\begin{tabular}{lccccc}
\hline & \multicolumn{2}{c}{ Maturus $(n=118)$} & & \multicolumn{2}{c}{ Maturus II $(n=103)$} \\
\cline { 2 - 3 } \cline { 5 - 6 } & Adequate PA & Inadequate PA & & Adequate PA & Inadequate PA \\
\hline Height $(\mathrm{cm})$ & $166.7 \pm 6.9$ & $166.5 \pm 9.5$ & & $160.6 \pm 7.7$ & $163.8 \pm 7.9$ \\
Weight $(\mathrm{kg})$ & $88.1 \pm 15.1$ & $95.2 \pm 18.1^{*}$ & & $84.4 \pm 11.8$ & $90.5 \pm 13.5^{*}$ \\
TBW $(1)$ & $37.7 \pm 4.8$ & $39.1 \pm 4.9$ & & $35.3 \pm 4.1$ & $37.8 \pm 4.2^{*}$ \\
ECW (1) & $14.3 \pm 1.8$ & $14.8 \pm 1.9$ & & $13.5 \pm 1.5$ & $14.5 \pm 1.7^{*}$ \\
ICW (1) & $23.4 \pm 3.1$ & $24.1 \pm 3.1$ & & $21.8 \pm 2.5$ & $23.3 \pm 2.5^{*}$ \\
FFM (kg) & $51.5 \pm 6.6$ & $53.3 \pm 6.6$ & & $48.2 \pm 5.5$ & $51.5 \pm 5.8^{*}$ \\
FFP (\%) & $58.9 \pm 5.5$ & $56.8 \pm 6.5$ & & $57.4 \pm 4.9$ & $57.4 \pm 5.7$ \\
BFM (kg) & $36.5 \pm 10.2$ & $41.9 \pm 13.5^{*}$ & & $36.2 \pm 8.3$ & $39.1 \pm 10.4$ \\
BFP (\%) & $40.9 \pm 5.5$ & $43.2 \pm 6.4$ & & $42.5 \pm 4.9$ & $42.5 \pm 5.7$ \\
BCM (kg) & $33.5 \pm 4.3$ & $34.6 \pm 4.3$ & & $31.2 \pm 3.6$ & $33.4 \pm 3.7^{*}$ \\
SMM (kg) & $28.5 \pm 3.9$ & $29.5 \pm 3.9$ & & $26.4 \pm 3.3$ & $28.4 \pm 3.3^{*}$ \\
VFA (cm $\left.{ }^{2}\right)$ & $138.1 \pm 38.7$ & $156.5 \pm 48.9^{*}$ & & $155.1 \pm 28.2$ & $162.7 \pm 38.9$ \\
\hline
\end{tabular}

Note. $\mathrm{PA}=$ physical activity, $\mathrm{TBW}=$ Total Body Water, $\mathrm{ECW}=$ Extracellular Body Water, ICW $=$ Intracellular Body Water, FFM = Fat-free Mass, FFP $=$ Fat-free Percentage, BFM = Body Fat Mass, BFP = Body Fat Percentage, BCM = Body Cell Mass, SMM = Skeletal Muscle Mass, VFA = Visceral Fat Area. Values are given as $M \pm S D$. *statistically significant difference between women with adequate and inadequate PA $(p<.05)$.

body fat. In body composition health indicators we observed significant health risks, namely exceeding the threshold limit.

Representation of the BFM (Body Fat Mass, kg) was very high, exceeding $35 \mathrm{~kg}$, and the relative value of the BFP (Body Fat Percentage, \%) reached $40 \%$. In older women with inadequate PA we observed higher values of the VFA, which greatly exceeded the recommended value $\left(>100 \mathrm{~cm}^{2}\right)$. Younger and also older women who achieved adequate PA reached lower average values of monitored parameters, i.e. the fat fraction (BFM, BFP) and also VFA. In younger women we found statistically significant differences in parameters associated with the risk aspects of obesity, specifically 
in body weight $(\mathrm{kg})$, BFM and VFA. In older women with adequate PA we found statistically significant differences in the TBW, FFM (Fat-free Mass, kg), BCM (Body Cell Mass, kg) and in SMM (Skeletal Muscle Mass, kg). A higher value of relative Fat-free Mass (FFP: Fat-free Percentage, \%) and lower value of BFP was found in younger active women, than in women with inadequate PA, however the differences were not statistically significant.

The relative risk of damage to health, as measured by the BMI, was high (Table 3 ). The average BMI values were within the obesity category $\left(\mathrm{BMI} \geq 30 \mathrm{~kg} / \mathrm{m}^{2}\right)$. BMI does not cover variability and changes in BFM and FFM. For more objective assessment of the relative risk of damage to health the BFMI and FFMI were used. BMI $\geq 30 \mathrm{~kg} / \mathrm{m}^{2}$ classification is set to be equivalent to the BFMI $\geq 11.8 \mathrm{~kg} / \mathrm{m}^{2}$ and FFMI $\geq 18.2 \mathrm{~kg} / \mathrm{m}^{2}$, which does correspond to our results (Schutz, Kyle, \& Pichard, 2002; Kyle et al., 2004). The index of metabolically active cells (BCMI, Body Cell Mass Index; 11.90 to $12.31 \mathrm{~kg} / \mathrm{m}^{2}$ ) corresponds to the health recommendations for women (Talluri et al., 2003).

\section{Discussion}

One aspect of the increasing prevalence of excess weight and obesity is widespread reduction in the PA, however it is largely habitual. Assessment of PA using the accelerometer is a good indicator and motivator, and it also serves as cognizance of the level and intensity of the PA carried out. The positive effect of PA on the body composition had often been confirmed. From the somatic viewpoint impact of PA is primarily perceived by the reduction of the fat component and increase in muscle mass (Sofková et al., 2014). Ross and Janiszewski (2008) and King, Hopkins, Caudwell, Stubbs, and Blundell (2009) have shown that the PA can provide health benefits and thus reduce the risk of obesity complications and improve mental well-being.
Appropriate PA, which is available to everyone, regardless of age and gender, is walking.

Women with active PA level, owing to the daily number of steps and Tudor-Locke and Bassett (2004) classification, may be classified as active individuals and women with inactive PA level are considered as individuals with typical daily activities. Chan, Spangler, Valcour, and Tudor-Locke (2003) and TudorLocke and Myers (2001) pointed out that the smaller number of steps is related to the higher BMI. Repka, Šebrle, Frömel, Chmelík, and Vašíčková (2011) and Whitt, Kumanyika, and Bellamy (2003) confirm that women with $\mathrm{BMI}<25$ carry out PA at higher level and walk greater number of steps per day than overweight and obese women. Wyatt, Peters, Reed, Barry, and Hill (2005) demonstrated that obese people (BMI > 30) walk 2,000 steps per day less than individuals with normal body weight. Tudor-Locke and Myers (2001) results indicate that more than, approximately, 9,000 steps/day is beneficial for the body composition and number of steps less 5,000 per day testifies to a sedentary way of life in the context of an unhealthy body composition.

The most variable component of body mass is fat, which is easily susceptible to developmental aspects and PA (Riegerová et al., 2006). On the basis of the fat fraction percentage average values, according to Heyward and Wagner (2004), groups of women that were classified as obese had more than $35 \%$ of the fat component. The fat component (BFP) exceeded in all sub-groups the $40 \%$ threshold, which is associated with significant negative health consequences. The increase of the fat component in relation to increasing age is confirmed, for example, by Kyle, Genton, Slosman, and Pichard (2001). Guo, Zeller, Chumlea, and Siervogel (1999) state that in adulthood the total amount of body fat increases approximately by $0.37 \mathrm{~kg}$ per year for men and $0.41 \mathrm{~kg}$ for women. Body fat distribution is determined genetically and partially regulated hormonally; consequently in postmenopausal women we

Table 3

Indices of selected body composition health indicators

\begin{tabular}{lccccc}
\hline & \multicolumn{2}{c}{ Maturus I $(n=118)$} & & \multicolumn{2}{c}{ Maturus II $(n=103)$} \\
\cline { 2 - 3 } \cline { 5 - 6 } & Adequate PA & Inadequate PA & & Adequate PA & Inadequate PA \\
\hline BMI $\left(\mathrm{kg} / \mathrm{m}^{2}\right)$ & $31.8 \pm 4.5$ & $34.6 \pm 4.3$ & & $31.9 \pm 3.7$ & $33.2 \pm 5.1$ \\
BFMI $\left(\mathrm{kg} / \mathrm{m}^{2}\right)$ & $13.2 \pm 3.5$ & $15.1 \pm 5.1$ & & $13.7 \pm 3.1$ & $14.3 \pm 4.1$ \\
FFMI $\left(\mathrm{kg} / \mathrm{m}^{2}\right)$ & $18.6 \pm 1.6$ & $18.9 \pm 1.9$ & & $18.2 \pm 1.2$ & $18.8 \pm 1.4^{*}$ \\
BCMI $\left(\mathrm{kg} / \mathrm{m}^{2}\right)$ & $12.1 \pm 1.1$ & $12.3 \pm 1.3$ & & $11.9 \pm 0.8$ & $12.2 \pm 0.9^{*}$ \\
\hline
\end{tabular}

Note. $\quad \mathrm{PA}=$ physical activity, BMI = Body Mass Index, BFMI = Body Fat Mass Index, FFMI = Fat-free Mass Index, $\mathrm{BCMI}=$ Body Cell Mass Index. Values are given as $M \pm S D .{ }^{*}$ statistically significant difference between women with adequate and inadequate PA $(p<.05)$. 
may observe its redistribution from the peripheries to the abdomen (Toth, Tchernof, Sites, \& Poehlman, 2000). Higher values of visceral fat determine abdominal obesity, one of the main assessment criteria of the metabolic syndrome, and they have almost comparable predictive value for major cardiovascular events as the increased levels of LDL cholesterol (Dukát et al., 2007). Average values of VFA reached in all sub-groups significant health risk threshold and ranged between 138.1 to $162.7 \mathrm{~cm}^{2}$.

A change in approach to PA is demonstrated by greater decreases in fat fraction and maintaining fat-free mass (Sofková, Přidalová, Pelclová, \& Dostálová, 2011). The greater the HPA level, the lower are the body composition health indicators, BMI and BFMI, which indicate the risk of obesity. In contrast, we find higher values of FFM, BCM and derived indices, FFMI and BCMI. Change in body fat precedes change in mass, particularly in people who sufficiently increased their PA (Sofková et al., 2014). Also studies of 69 African-American women aged 40 to 62 years (Hornbuckle, Basset, \& Thompson, 2005) and 80 middle-aged women in the USA (Thompson, Rakow, \& Perdue, 2004) showed a clear inverse relationship between the number of steps per day and the percentage of body fat. Engaging in everyday PA brings great benefits and is significantly reflected in body composition (Gába et al., 2009). Sofková, Přidalová, Mitáš, and Pelclova (2013) point to the fact that increase in walking is positively reflected into the healthier body composition.

There is a reciprocal relationship between the total body water and fat content. The water content is low in obese people, which makes up only $45 \%$ of body mass. Rokyta (2000) reported that the water content in the adipose tissue is only $10 \%$. In younger women, we recorded $41.9 \%$ water in body weight (TBW: 38.41 , weight: $91.6 \mathrm{~kg}$ ) and $41.7 \%$ in older women (TBW: 36.5 1, weight: $87.4 \mathrm{~kg}$ ). Gába and Přidalová (2014), Bedogni et al. (2002) and Ling et al. (2011) point to the decrease in TBW in relation to increasing age. Also Přidalová et al. (2008) and Přidalová, Sofková, Dostálová, and Gába (2011) demonstrated that in Czech women the TBW decreases with age and with the increase in BMI and proportion of the fat component (BFM).

In monitored sub-groups FFM decreases with age and the PA level. Representation of FFP in younger women was about $57.9 \%$ and $57.4 \%$ in older women. The older women with inadequate PA are the greater decrease in the amount of FFM. Gába and Přidalová (2014) point to the relationship of increasing age to slight decrease in FFM and at the same time increase in masse due the BFM increase.

\section{Conclusions}

Based on the PA monitoring and body composition health indicators associated with the obesity risk aspects we noted in obese and overweight women who had active level of PA lower levels of body fat (BFP, BFM) and less VFA in both age groups in comparison with women with inactive PA level. At the same time we recorded the increase in fat-free body mass (FFP, FFM).

Relative risk of damage to health as measured by the somatic indices (BMI, BFMI) is high in women irrespective of the PA level carried out.

Positive approach to PA focused on health promotion and healthy lifestyle may lead to smaller number of health problems associated with obesity. The relationship between health indicators of body composition and meeting recommended PA might be useful in strategies aimed at maintaining and developing a healthy lifestyle. Overweight and obesity do not constitute a significant barrier in undertaking an adequate level of PA.

\section{Acknowledgment}

The study was carried out within the IGA UP project "The relationship between the health indicators and physical activity in obese and overweight women" (No. FTK_2012_030).

\section{References}

Andersen, R. E. (2003). Obesity. Etiology, assessment, treatment, and prevention. Champaign, IL: Human Kinetics.

Ball, K., Crawford, D., \& Owen, N. (2000). Too fat to exercise? Obesity as a barrier to physical activity. Australian and New Zealand Journal of Public Health, 24, 331-333.

Bedogni, G., Malavolti, M., Severi, S., Poli, M., Mussi, C., Fantuzzi, A. L., \& Battistini, N. (2002). Accuracy of an eight point tactile-electrode impedance method in the assessment of total body water. European Journal of Clinical Nutrition, 56, 1143-1148.

Biospace. (2008). InBody 720 - The precision body composition analyzer (User's manual). Seoul, South Korea: Author.

Chan, C. B., Spangler, E., Valcour, J., \& Tudor-Locke, C. (2003). Cross-sectional relationship of pedometer-determined ambulatory activity to indicators of health. Obesity Research, 11, 1563-1570.

Cibula, D., Henzl, M. R., \& Živný, J. (2002). Základy gynekologické endokrinologie [Fundamentals of gynaecological endocrinology]. Praha, Czech Republic: Grada.

Doll, H. A., Petersen, S., \& Stewart-Brown, S. L. (2000). Obesity and physical and emotional well-being: Associations between body mass index, chronic illness, and the physical and mental compartments of the SF-36 questionnaire. Obesity Research, 8, 160-170. 
Dukát, A., Lietava, J., Krahulec, B., Čaprnda, M., Vacula, I., Sirotiaková, J., ... Minárik, P. (2007). Prevalencia abdominálnej obezity na Slovensku, študia IDEA Slovakia [The prevalence of abdominal obesity in Slovakia. The IDEA Slovakia study]. Vnitřní lékařství, 53, 326-330.

Fanta, M. (2007). Kontracepce v perimenopauze [Contraception in perimenopause]. Sanquis, 54, 18.

Gába, A., Pelclová, J., Přidalová, M., Riegerová, J., Dostálová, I., \& Engelová, L. (2009). The evaluation of body composition in relation to physical activity in 56-73 year old women: A pilot study. Acta Universitatis Palackianae Olomucensis. Gymnica, 39(3), 21-30.

Gába, A., \& Přidalová, M. (2014). Age-related changes in body composition in a sample of Czech women aged 18-89 years: A cross-sectional study. European Journal of Nutrition, 53, 167-176.

Guo, S. S., Zeller, C. H., Chumlea, C. W., \& Siervogel, R. M. (1999). Aging, body composition, and lifestyle: The Fels Longitudinal Study. American Journal of Clinical Nutrition, 70, 405-411.

Haskell, W. L., Lee, I. M., Pate, R. R., Powell, K. E., Blair, S. N., \& Franklin, B. A. (2007). Physical activity and public health: Updated recommendation for adults from the American College of Sports Medicine and the American Heart Association. Circulation, 116, 1081-1093.

Heyward, V. D., \& Wagner, D. R. (2004). Applied body composition assessment. Champaign, IL: Human Kinetics.

Hoeger, W. W. K., \& Hoeger, S. A. (2009). Fitness and wellness. Belmont, CA: Wadsworth Cengage Learning.

Hornbuckle, L. M., Bassett, D. R., \& Thompson, D. L. (2005). Pedometer-determined walking and body composition variables in African-American women. Medicine \& Science in Sports \& Exercise, 37, 1069-1074.

Jeffery, R. W., Wing, R. R., Sherwood, N. E., \& Tate, D. F. (2003). Physical activity and weight loss: Does prescribing higher physical activity goals improve outcome? American Journal of Clinical Nutrition, 78, 684-689.

Kalvach, Z., Zadák, Z., Jirák, R., Zavázalová, H., \& Sucharda, P. (2004). Geriatrie a gerontologie [Geriatrics and gerontology]. Praha, Czech Republic: Grada.

King, N. A., Hopkins, M., Caudwell, P., Stubbs, R. J., \& Blundell, J. E. (2009). Beneficial effects of exercise: Shifting the focus from body weight to other markers of health. British Journal of Sports Medicine, 43, 924-927.

Kyle, U. G., Genton, L., Slosman, D. O., \& Pichard, C. (2001). Fat-free and fat mass percentiles in 5225 healthy subjects aged 15 to 98 years. Nutrition, 17, 534-541.

Kyle, U. G., Morabia, A., Schutz, Y., \& Pichard, C. (2004). Sedentarism affects body fat mass index and Fat-free Mass index in adults aged 18 to 98 years. Nutrition, 20, 255-260.

Ling, C. H., De Craen, A. J., Slagboom, P. E., Gunn, D. A., Stokkel, M. P., Westendorp, R. G., \& Maier, A. B. (2011). Accuracy of direct segmental multi-frequency bioimpedance analysis in the assessment of total body and segmental body composition in middle-aged adult population. Clinical Nutrition, 30, 610-615.

Miles, M. (2007). Disability and deafness in East Asia: Social and educational responses, from Antiquity to recent times. Retrieved from http://independentliving.org/docs7/ miles200708.html
Murphy, S. L. (2009). Review of physical activity measurement using accelerometers in older adults: Considerations for research design and conduct. Preventive Medicine, 48, 108-114.

Norman, A., Bellocco, R., Vaida, F., \& Wolk, A. (2002). Total physical activity in relation to age, body mass, health and other factors in a cohort of Swedish men. International Journal of Obesity and Related Metabolic Disorders, 26, 670-675.

Přidalová, M., Riegerová, J., Dostálová, I., \& Gába, A. (2008). Effects of cognitive behavioral psychotherapy on body composition and constitution. Acta Universitatis Palackianae Olomucensis. Gymnica, 38(2), 13-23.

Přidalová, M., Sofková, T., Dostálová, I., \& Gába, A. (2011). Vybrané zdravotní ukazatele u žen s nadváhou a obezitou ve věku 20-60 let [Selected health indicators in women with overweight and obesity at the age of 20-60 years]. Česká antropologie, 61(1), 32-38.

Riegerová, J., Přidalová, M., \& Ulbrichová, M. (2006). Aplikace fyzické antropologie $v$ tělesné výchově a sportu [Application of physical anthropology in physical education and sports]. Olomouc, Czech Republic: Hanex.

Rokyta, R. (2000). Fyziologie pro bakalárská studia v medicíně, prírodovědných a tělovýchovných oborech [Physiology for bachelor's studies of medicine, sciences and physical education]. Praha, Czech Republic: ISV nakladatelství.

Ross, R., \& Janiszewski, P. M. (2008). Is weight loss the optimal target for obesity - related cardiovascular disease risk reduction? Canadian Journal of Cardiology, 24, 25-31.

Řepka, E., Šebrle, Z., Frömel, K., Chmelík, F., \& Vašičková, Z. (2011). Plnění doporučení k týdenní pohybové aktivitě dospělou populací jihočeského regionu [Carrying out recommendations for weekly physical activity by the adult population of the South Bohemian region]. Tělesná kultura, 34(1), 64-74.

Saris, W. H. M., Blair, S. N., Van Baak, M. A., Eaton, S. B., Davies, P. S., Di Pietro, L., ... Wyatt, H. (2003). How much physical activity is enough to prevent unhealthy weight gain? Outcome of the IASO $1^{\text {st }}$ Stock Conference and consensus statement. Obesity Reviews, 4, 101-114.

Schutz, Y., Kyle, U. G., \& Pichard, C. (2002). Fat-free mass index and fat mass index percentiles in Caucasians aged 18-98 y. International Journal of Obesity and Related Metabolic Disorders, 26, 953-960.

Sofková, T., Přidalová, M., Mitáš, J., \& Pelclová, J. (2013). The level of neighborhood walkability in a place of residence and its effect on body composition in obese and overweight women. Central European Journal of Public Health, 21, 184-189.

Sofková, T., Přidalová, M., \& Pelclová, J. (2014). The effect of movement intervention for women attending courses in weight reduction. Acta Gymnica, 44, 47-56.

Sofková, T., Přidalová, M., Pelclová, J., \& Dostálová, I. (2011). Změna tukové frakce u obézních žen ve vztahu $\mathrm{k}$ doporučené pohybové aktivitě [Changes in fat fraction in obese women in relation to recommended physical activity]. Česká antropologie, 61(1), 39-44.

Talluri, A., Liedtke, R., Mohamed, E. I., Maiolo, C., Martinoli, R., \& Lorenzo, A. (2003). Application of body cell mass index for studying muscle mass changes in health and disease conditions. Acta Diabetologica, 40, 286-289. 
Thompson, D. L., Rakow, J., \& Perdue, S. M. (2004). Relationship between accumulated walking and body composition in middle-aged women. Medicine \& Science in Sports \& Exercise, 36, 911-914.

Toth, M. J., Tchernof, A., Sites, C. K., \& Poehlman, E. T. (2000). Effect of menopausal status on body composition and abdominal fat distribution. International Journal of Obesity, 24, 226-231.

Trost, S., McIver, K., \& Pate, R. (2005). Conducting accelerometer-based activity assessments in field-based research. Medicine \& Science in Sports \& Exercise, 37, 531-543.

Tudor-Locke, C., \& Bassett, R. (2004). How many steps/ day are enough? Preliminary pedometer indices for public health. Sports Medicine, 34, 1-8.

Tudor-Locke, C., \& Myers, A. M. (2001). Methodological considerations for researchers and practitioners using pedometers to measure physical (ambulatory) activity. Research Quarterly for Exercise and Sport, 72, 1-12.
U.S. Department of Health and Human Services. (2008). Physical activity guidelines for Americans. Retrieved from http://www.health.gov/paguidelines/pdf/paguide.pdf

Varo, J. J., Martinez-Gonzalez, M. A., de Irala-Estevez, J., Kearney, J., Gibney, M., \& Martinez, J. A. (2003). Distribution and determinants of sedentary lifestyles in the European Union. International Journal of Epidemiology, 32, 138-146.

Whitt, M. C., Kumanyika, S., \& Bellamy, S. (2003). Amount and bouts of physical activity in a sample of African-American women. Medicine \& Science in Sports \& Exercise, 35, 1887-1893.

World Health Organization (WHO). (2004). Global strategy on diet, physical activity and health. Geneva, Switzerland: Author.

Wyatt, H. R., Peters, J. C., Reed, G. V., Barry, M., \& Hill, J. O. (2005). A Colorado statewide survey of walking and its relation to excessive weight. Medicine \& Science in Sports \& Exercise, 37, 724-730. 